Journal of Economic, Business and Accounting (COSTING)

Volume 1 Nomor 2, Juni 2018

e-ISSN : 2597-5234

https://doi.org/10.31539/costing.v1i2.266

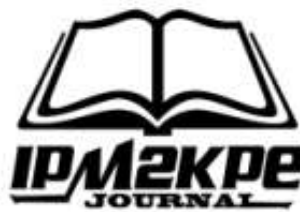

\title{
KOMPARATIVE PENGARUH DOMINAN CURRENT RATIO DAN DEBT \\ TO EQUITY RASIO TERHADAP RETURN ON ASSETS \\ PADA PERUSAHAAN KOSMETIK YANG TERDAFTAR \\ DI BURSA EFEK INDONESIA TAHUN 2012-2016
}

\author{
COMPARATIVE DOMINANT INFLUENCE CURRENT RATIO AND DEBT \\ TO EQUITY RASIO TO RETURN ON ASSETS ON COSMETICS COMPANIES \\ LISTED ON THE STOCK EXCHANGE IN 2012-2016
}

\author{
Rina Milyati Yuniastuti \\ Sekolah Tinggi Ilmu Ekonomi Prasetiya Mandiri Lampung \\ rinamilyati@gmail.com
}

\begin{abstract}
The financial statements are very useful for decision making, throug financial statement information can be predicted what will happen to the company in the future. The purpose of this study is to determine the most dominant influence between current ratio and Debt to Equity ratio to return on Assets on cosmetics companies listed on the Stock Exchange. Long-term contribution in research to provide information about the dominant influence between current ratio and debt to equity ratio to return on assets which is useful for the investors. Method used in this research is documentation method, that is research which use data collecting method by looking at report finance. The result of this research is Current ratio has more dominant influence to ROA compared to Debt to Equity ratio to ROA.
\end{abstract}

Keywords: Dominant Influence, Current ratio, Debt to Equity ratio, Return on Assets

\begin{abstract}
ABSTRAK
Laporan keuangan sangat bermanfaat untuk pengambilan keputusan, amelalui informasi laporan keuangan tersebut dapat diprediksi apa yang akan terjadi pada perusahaan di masa yang akan datang. Tujuan penelitian ini yang ingin dicapai adalah untuk mengetahui pengaruh yang paling dominan antara current ratio dan Debt to Equity rasio terhadap return on Assets pada perusahaan kosmetik yang terdaftar di BEI. Kontribusi jangka panjang dalam penelitian untuk memberikan informasi akan pengaruh yang dominan antara current ratio dan debt to equity ratio terhadap return on assets yang berguna bagi para investor.Metode yang digunakan dalam penelitian ini adalah metode dokumentasi,yaitu penelitian yang menggunakan metode pengumpulan data dengan melihat laporan keuangan . Hasil dari penelitian ini adalah Current rasio mempunyai pengaruh yang lebih dominan terhadap ROA dibandingkan dengan Debt to Equity rasio terhadap ROA.
\end{abstract}

Kata Kunci :Pengaruh Dominan,Current ratio,Debt to Equity ratio, Return on Assets 


\section{PENDAHULUAN}

Di Era sekarang ini,sudah semestinya perusahaan harus dapat dan mampu bersaing dengan perusahaan lain yang sejenis tentunya.Hal ini karena banyak perusahaan yang bergerak di bidang atau di industri yang sama mengalami kerugian .Kerugian ini salah satunya berasal dari masuknya produk dari luar negeri yang murah dan sangat menarik.Salah satu produk tersebut adalah kosmetik.Kosmetik merupakan salah satu unsur yang dapat mempercantik kaum hawa.Perusahaan ini biasa disebut dengan nama perusahaan kosmetik. Kosmetik merupakan zat perawatan yang digunakan untuk meningkatkan penampilan khususnya kaum hawa, seperti mempercantik, membersihkan,mempromosikan daya tarik atau mengubah penampilan tanpa mempengaruhi struktur atau fungsi tubuh. Karena sangat pentingnya manfaat kosmetik ini maka dalam menjalankan suatu bisnis tentunya perusahaan harus mempunyai suatu laporan keuangan (Financial Statement). Dari laporan keuangan akan menjadi lebih bermanfaat untuk pengambilan keputusan, apabila dengan informasi laporan keuangan tersebut dapat diprediksi apa yang akan terjadi dimasa yang akan datang. Dengan mengolah lebih lanjut laporan keuangan melalui proses perbandingan ,evaluasi dan analisis yang akan diperoleh prediksi tentang apa yang mungkin terjadi di masa mendatang sehingga disinilah laporan keuangan tersebut diperlukan.

Salah satu bentuk rasio profitabilitas untuk mengukur kemampuan perusahaan dalam menghasilkan laba dengan menggunakan total aktiva yang ada dan setelah biaya biaya modal dikeluarkan adalah ROA (Return On Assets).Suatu
ROA yang positif menunjukkan bahwa dari total aktiva yang dipergunakan untuk operasi perusahaan mampu memberikan laba bagi perusahaan Sebaliknya jika ROA negatif menunjukkan total aktiva yang dipergunakan tidak memberikan laba atau keuntungan. Sedangkan pada Likuiditas ( Current rasio) merupakan rasio untuk mengukur kemampuan perusahaan dalam membayar kewajiban jangka pendek atau uang yang segera jatuh tempo pada saat ditagih secara keseluruhan. Sedangkan pada solvabilitas ( Debt to Equity Rasio)/DER untuk mengetahui jumlah dana yang disediakan pinjaman (kreditor) dengan pemilik perusahaaan.

Penelitian ini ingin mengkaji lebih dalam kemampuan perusahaan membayar kewajiban jangka pendeknya /Current rasio (CR) terhadap keuntungan yang diperoleh,begitu juga pada DER dengan adanya penambahan dana dari pihak kreditor/pihak ketiga diharapakan akan efektif dalam menghasilkan laba. Hasil penelitian terdahulu yang dilakukan Jhon $\mathrm{N}$ (2016) pada dua objek perusahaan yang berbeda dan peneliti menggunakan uji simultan menunjukkan bahwa tidak ada pengaruh antara current rasio terhadap ROA.Hal ini menunjukkan bahwa perusahaan dapat menghasilkan laba dan harus bisa membayar kewajiban jangka pendeknya dengan tepat waktu. Selain faktor profitabilitas,juga di faktor solvabilitas yang di uji dengan rasio Debt to Equity/rasio hutang,menunjukkan bahwa rasio ini mengukur sejauh mana perusahaan dibiayai dari pinjaman.Menurut Mahardhika,Marbun (2016) bahwa DER mempunyai pengaruh signifikan negatif terhadap ROA. Hal ini berarti jika DER meningkat maka ROA akan 
mengalami penurunan.Sehingga jika penggunaan hutang dalam kegiatan pendanaan perusahaan tidak diperhatikan maka akan memberikan dampak yang kurang bagi bagi perusahaan,yaitu menurunnya keuntungan.

Penelitian ini berbeda dengan penelitian terdahulu yaitu pada objek perusahaan yang digunakan sebagai sampel adalah perusahaan kosmetik dengan data sebanyak 5 tahun yaitu dari tahun 2012-2016. Dan variabel yang digunakan adalah Likuiditas dengan Current Rasio (CR),Solvabilitas dengan Debt to Equity Rasio (DER) serta Profitabilitas dengan Return On Assets (ROA).

Tujuan penelitian ini adalah : untuk menganalisis rasio mana yang berpengaruh dominan antara Current rasio dan Debt to Equity rasio terhadap Return on Assets pada perusahaan kosmetik yang terdaftar di bursa efek Indonesia tahun 2012-2016.

Menurut Kasmir (2011 :128) analisis rasio keuangan dibagi atas 4 rasio keuangan yaitu :

Rasio likuiditas (Liquidity Ratio) Merupakan rasio yang menggambarkan kemampuan perusahaan dalam memenuhi kewajiban (utang) jangka pendek. Artinya apabila perusahaan ditagih , perusahaan akan mampu untuk memenuhi utang tersebut, terutama utang yang sudah jatuh tempo.

Jenis-jenis Rasio Likuiditas

1. Rasio lancar ( current ratio ) : Rasio lancar atau (current ratio) merupakan seberapa banyak aktiva lancar yang tersedia untuk menutupi kewajiban jangka pendek yang segera jatuh tempo.

Current ratio $=$ Aktiva Lancar

hutang lancar
2. Rasio Cepat ( quick Ratio) : Rasio cepat ( quick Ratio ) atau rasio sangat lancar atau acid test ratio merupakan rasio yang menunjukkan kemampuan perusahaan dalam memenuhi atau membayar kewajiban atau utang lancar ( utang jangka pendek) dengan aktiva lancar tanpa memperhitungkan nilai sediaan (inventory).

Quick Ratio $=$ Aktiva Lancar - Persediaan Hutang lancar

3. Rasio Kas (Cash Ratio) : Rasio kas atau cash ratio merupakan alat yang digunakan untuk mengukur seberapa besar uang kas yang tersedia untuk membayar utang.

Cash Ratio $=$ kas + bank

Hutang lancar

4. Rasio Perputaran Kas ( Cash turn over ) : Rasio perputaran kas (Cash turn over ) berfungsi untuk mengukur tingkat kecukupan modal kerja perusahaan yang dibutuhkan untuk membayar tagihan dan membiayai penjualan. Hasil perhitungan rasio perputaran kas dapat diartikan sebagai berikut:

- Apabila rasio perputaran kas tinggi,ini berarti, ketidakmampuan perusahaan dalam membayar tagihannya.

- Sebaliknya apabila rasio perputaran kas rendah, dapat diartikan kas yang tertanam pada aktiva yang sulit dicairkan dalam waktu singkat sehingga perusahaan harus bekerja keras dengan kas yang lebih sedikit.

Rasio Perputaran kas $=$ Penjualan bersih

Modal kerja bersih 
Rasio Solvabilitas

Leverage Ratio ) : Merupakan rasio yang digunakan mengukur sejauh mana aktiva perusahaan dibiayai dengan utang.Dalam arti luas dikatakan bahwa rasio solvabilitas digunakan untuk mengukur kemampuan perusahaan untuk membayar seluruh kewajibannya , baik jangka pendek maupun jangka panjang apabila perusahaan dibubarkan (dilikuidasi).

Jenis-jenis Rasio Solvabilitas

1.Debt to Asset Ratio ( Debt Ratio )

Merupakan ratio utang yang digunakan untuk mengukur perbandingan antara total utang dengan total aktiva. Dengan kata lain, seberapa besar aktiva perusahaan dibiayai oleh utang atau seberapa besar utang perusahaan berpengaruh terhadap pengelolaan aktiva.

Debt to Asset ratio $=$ Total utang

$$
\text { Total aktiva }
$$

\section{Debt to Equity Ratio}

Merupakan rasio yang digunakan untuk menilai utang dengan ekuitas.Rasio ini berguna untuk mengetahui jumlah dana yang disediakan peminjam (kreditor) dengan pemilik perusahaan. Rumus untuk mencari Debt to Eguity Ratio dapat digunakan perbandingan antara total utang dengan total ekuitas sebagai berikut :

Debt to Eguity Ratio = Total utang

\section{Ekuitas}

\section{Long term Debt to Equity Ratio (LTDtER)}

Merupakan rasio antara utang jangka panjang dengan model sendiri.

LTDtER
panjang

Total Equity

\section{Times Interest Earned}

Merupakan rasio untuk mencari jumlah kali perolehan bunga. Rasio ini diartikan sebagai kemampan perusahaan untuk membayar biaya bunga, sama seperti Coverage Ratio.

Times interest earned $=$ EBIT

$$
\text { Biaya bunga }
$$

Rasio Aktivitas (activity ratio) merupakan rasio yang digunakan untuk mengukur efektivitas perusahaan dalam menggunakan aktiva yang dimilikinya. Atau dapat pula dikatakan rasio ini digunakan untuk mengukur tingkat efisiensi (efektivitas) pemanfaatan sumber daya perusahaan. Efisiensi yang dilakukan misalnya dibidang penjualan, sediaan,penagihan piutang dan efisiensi dibidang lainnya. Rasio aktivitas juga digunakan untuk menilai kemampuan perusahaan dalam melaksanaan aktivitas sehari-hari. Dari hasil pengukuran dengan rasio aktivitas akan terlihat apakah persahaan lebih efisien dan efektif dalam mengelola aset yang dimilikinya atau mungkin justru sebaliknya.

$$
\text { Jenis-Jenis Rasio Aktivitas }
$$

1.Perputaran Piutang ( Receivable turn over )

Perputaran piutang merupakan rasio yang digunakan untuk mengukur berama lama penagihan piutang selama satu periode atau berapa kali dana yang ditanam dalam piutang ini berputar dalam dalam satu periode.

$$
\text { Perputaran piutang }=\frac{\text { Penjualan kredit }}{\text { Rata-rata Piutang }}
$$

\section{Perputaran Sediaan ( Inventory Turn} Over )

Perputaran sediaan merupakan rasio yang digunakan untuk mengukur berapa kali dana yang ditanam dalam sediaan (inventory) ini berputar dalam satu periode 
Inventory turn over $=$ Harga pokok barang yang dijual

Persediaan

3.Perputaran Modal Kerja ( Working Capital Turn Over )

Perputaran modal kerja atau working capital turn over merupakan salah satu rasio untuk mengukur atau menilai keefektifan modal kerja perusahaan selama periode tertentu.

Perputaran modal kerja $=$ Penjualan bersih

Modal kerja rata-rata

\section{Fixes Assets Turn Over}

Merupakan rasio yang digunakan untuk mengukur berapa kali dana yang ditanamkan dalam aktiva tetap berputar dalam satu periode.

Fixed Assets turn over $=\quad$ Penjualan

Total Aktiva Tetap

\section{Total Assets Turn Over}

Merupakan rasio yang digunakan untuk mengukur perputaran semua aktiva yang dimiliki perusahaan dan mengukur berapa jumlah penjualan yang diperoleh dari tiap rupiah aktiva.

Total asset turn over $=$ Penjualan

$$
\text { Total Aktiva }
$$

Rasio Profitabilitas merupakan rasio untuk menilai kemampuan perusahaan dalam mencari keuntungan. Rasio ini juga memberikan ukuran tingkat efektivitas manajemen suatu perusahaan. Hal ini ditunjukkan oleh laba yang dihasilkan dari penjualan dan pendapatan investasi. Intinya adalah penggunaan rasio ini menujukkan efisiensi perusahaan.

Jenis-jenis Rasio Profitabilitas :

\section{Profit Margin on Sales}

Profit margin on sales atau ratio profit margin atau margin laba atas penjualan merupakan salah satu rasio yang digunakan untuk mengukur margin laba atas penjualan. Cara pengukuran rasio ini adalah dengan membandingkan laba bersih setelah pajak dengan penjualan bersih . rasio ini juga dikenal dengan nama profit margin.Terdapat dua rumus untk mencari profit margin, yaitu sebagai berikut :

a.Untuk margin laba kotor dengan rumus :

Profit margin $=$ Penjualan bersih - HPP

Margin $^{\text {Sales }}$ laba kotor menunjukkan laba yang relative terhadap perusahaan, dengan cara penjualan bersih dikurangi harga pokok penjualan. Rasio ini merupakan cara untuk penetapan harga pokok penjualan .

Untuk margin laba bersih dengan rumus :

Net Profit Margin = EAIT

\section{Sales}

Margin laba bersih merupakan ukuran keuntungan dengan membandingkan antara laba setelah bunga dan pajak dibandingkan dengan penjualan. Rasio ini menunjukkan pendapatan bersih perusahaan atas penjualan.

2.Return On invesment (ROI) /Return On Assets Rasio (ROA)

Return On invesment atau return on asset menunjukan kemampuan perusahaan menghasilkan laba dari aktiva yang dipergunakaan.

$$
R O I=\frac{\text { Laba setelah pajak }}{\text { Total Assets }} \times 100 \%
$$


3.Return on Equity ( ROE)

$\begin{array}{ccr} & \text { Return on Equity (ROE) adalah } \\ \text { rasio } & \text { profitabilitas yang }\end{array}$ membandingkan antar laba bersih (net profit) perusahaan dengan aset bersihnya (ekuitas atau modal). Rasio ini mengukur berapa banyak keuntungan yang dihasilkan oleh Perusahaan dibandingkan dengan modal yang disetor oleh Pemegang Saham

Return on Equity = Laba bersih

Ekuitas

4.Laba Per Lembar Saham Biasa ( Earning per Share of Common Stock )

Rasio laba per lembar saham atau disebut juga rasio nilai buku merupakan rasio untuk mengukur keberhasilan manajemen dalam mencapai keuntungan bagi pemegang saham. Rasio yang rendah berarti manajemen belum berhasil untuk memuaskan pemegang saham ,sebaliknya dengan rasio yang tinggi ,kesejahteraan pemegang saham meningkat.

Laba per Lembar Saham = Laba saham biasa

Saham biasa yang beredar

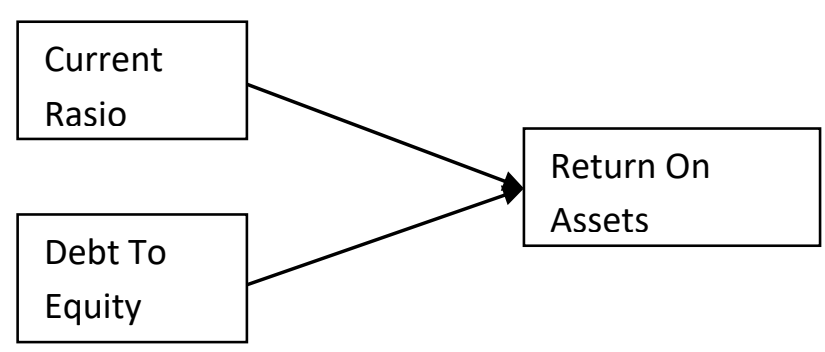

Sumber : Data Diolah

\section{Gambar 1.Skema Kerangka Pemikiran}

Berdasarkan

kerangka

pemikiran dapat dirumuskan hipotesis sebagai berikut: (1).Current Rasio berpengaruh terhadap ROA,(2).Debt to Equity Rasio berpengaruh terhadap ROA,(3).Current rasio lebih dominan berpengaruh terhadap ROA daripada Debt To Equity Rasio.

\section{METODE PENELITIAN}

\section{Populasi dan Sampel Penelitian}

Populasi yang diambil dalam penelitian ini adalah perusahaan kosmetik yang sudah terdaftar di Bursa Efek Indonesia ( BEI ). Sampel yang digunakan perusahaan menggunakan metode pruposive sampling yaitu teknik pengambilan sampel sumber data dengan pertimbangan tertentu.,Sugiyono (2011:126). Dan pertimbangan yang digunakan adalah sebagai berikut : (1).Perusahaan kosmetik yang terdaftar di Bursa Efek Indonesia (BEI) tahun 2012 2016.(2).Menyajikan laporan keuangan yang terlampir di tahun 2012- 2016.

Penelitian:

$$
\text { Daftar Kriteria Sampel }
$$

\begin{tabular}{lll}
\hline NO & Keterangan & Jumlah \\
\hline 1 & $\begin{array}{l}\text { Jumlah perusahaan } \\
\text { kosmetik yang terdaftar di } \\
\text { Bursa Efek Indonesia }\end{array}$ & 6 \\
& $\begin{array}{l}\text { Perusahaan yang } \\
\text { menyajikan laporan }\end{array}$ & 5 \\
\hline 2 & keuangan tahun 2012-2016 \\
\hline 3 & Jumlah sampel penelitian & 5 \\
\hline
\end{tabular}

\section{Teknik Pengumpulan Data}

Teknik Pengumpulan data dalam penelitian ini adalah teknik dokumentasi yaitu dengan cara mengumpulkan data sekunder yang diperoleh dari berbagai sumber. Dalam penelitian ini penulis mengumpulkan data sekunder berupa laporan keuangan tahunan pada perusahaan kosmetik yang telah terdaftar di Bursa Efek Indonesia melalui situs resmi BEI www.idx.co.id .

\section{Teknik analisis data}

Teknik analisis data yang digunakan dalam penelitian ini ada dua yaitu:Analisis Kualitatif adalah data yang didapatkan akan dianalisis dengan penilaian teoritis dan logis sesuai dengan pembuktian secara 
kuantitatifnya. Serta Analisis Kuantitatif adalah data yang dianalisis secara pembuktian angka angka sesuai dengan data yang di dapat dalam penelitian.

\section{Uji Asumsi Klasik}

Penelitian ini menggunakan salah satu uji asumsi klasik yaitu :Uji Normalitas bertujuan untuk menguji apakah dalam model regresi, variabel bebas dan variabel terikat keduanya mempunyai distribusi normal atau tidak .Uji Normalitas data dapat dilakukan dengan menggunakan Normal P-Plot of Regression Standardized Residual.kesimpulan untuk menentukan apakah suatu data mengikuti distribusi normal ataukah tidak adalah dengan variabel dependent mengikuti

lurus/diagonal.(Ghozali,2016).

\section{Uji Hipotesis}

\section{Uji Hipotesis Analisis Parsial (Uji t)}

Untuk mengetahui pengaruh secara parsial antara variabel terikat dengan variabel bebas (Priyatno,2012).Pengujian dilakukan dengan menggunakan program SPSS.Dan pengambilan keputusan membandingkan dengan signifikansi/probabilitas $<0,05$ maka H1 diterima dan Ho ditolak.

Uji Determinasi $\mathbf{R}^{2}$

Digunakan untuk Koefesien determinasi pada regresi linear sering diartikan seberapa besar kemampuan semua variabel bebas dalam menjelaskan varians dan variabel terikatnya. Secara sederhana koefisien determinasi dihitung dengan mengkuadratkan koefisien korelasi (R). $\mathrm{R}^{2}$ adalah angka yang menunjukkan seberapa \% Variabel terikat yang dipengaruhi oleh variabel bebas,atau dari $100 \%$ variabel yang berpengaruh terhadap variabel terikat dan dari sekian sisanya dipengaruhi variabel lain yang tidak diteliti,karena tidak dimasukan dalam data.Semakin besar nilai $\mathrm{R}^{2}$ maka semakin baik model tersebut.(Ghozali,2005).

\section{Definisi Operasional Variabel Variabel dependent}

Variabel dependent yang digunakan dalam penelitian ini adalah ROA sebagai berikut:

Rasio yang menunjukkan seberapa besar kontribusi assets dalam menciptakan laba bersih

$\mathrm{ROA}=$ Laba setelah pajak $\times 100 \%$

Total Assets

\section{Variabel Independent}

Variabel Independent yang digunakan dalam penelitian ini adalah :

1. Current Rasio

Rasio current merupakan rasio untuk mengukur kemampuan perusahaan dalam membayar kewajiban jangka pendek atau utang yang segera jatuh tempo pada saat ditagih secara keseluruhan.

Current ratio $=$ Aktiva Lancar

hutang lancar

2. Debt to Equity Rasio

Merupakan ratio utang yang digunakan untuk mengukur perbandingan antara total utang dengan equitas.

Debt to Asset ratio = Total utang

$$
\text { Equitas }
$$




\section{HASIL DAN PEMBAHASAN Uji klasik Normalitas}

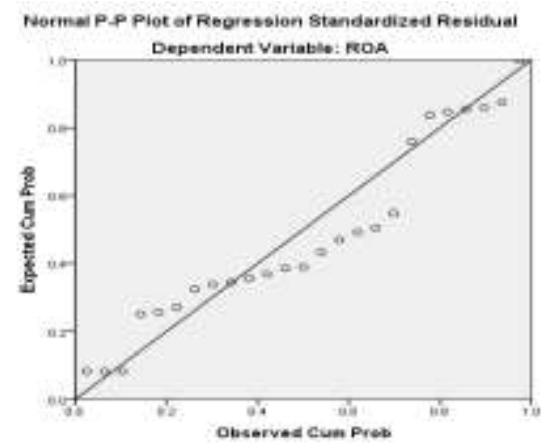

Gambar 1. Uji klasik Normalitas

Dari gambar diatas korelasi antara expected cum prob dan observed cum prob pada variabel dependen mengikuti sekitar garis lurus yang artinya residual adalah normal karena error variabel dependennya kecil.

Analisis Regresi

Pada Current rasio Terhadap Return on Assets:

\section{Tabel 1}

\section{Coefficients CR terhadap ROA}

\begin{tabular}{|c|c|c|c|c|c|c|}
\hline \multirow{2}{*}{\multicolumn{2}{|c|}{ Model }} & \multicolumn{2}{|c|}{$\begin{array}{l}\text { Unstandardized } \\
\text { Coefficients }\end{array}$} & \multirow{2}{*}{$\begin{array}{c}\begin{array}{c}\text { Standardized } \\
\text { Coefficients }\end{array} \\
\text { Beta }\end{array}$} & \multirow[t]{2}{*}{$\mathrm{t}$} & \multirow[t]{2}{*}{ Sig. } \\
\hline & & B & Std. Error & & & \\
\hline \multirow{2}{*}{1} & (Constant) & 2181.435 & 592.448 & & 3.682 & .001 \\
\hline & $\mathrm{CR}$ & -3.151 & 1.672 & -.366 & -1.885 & .072 \\
\hline
\end{tabular}

Dari tabel diatas didapat persamaan regresi linier sederhana sebagai berikut:

$\mathrm{ROA}=2181,435-3,151 \mathrm{X} 1$

Interprestasi yang di dapat dinyatakan dari persamaan diatas sebagai berikut:

1.Nilai kontantan sebesar 2181,435 yang artinya jika nilai CR ( Current Rasio) memiliki nilai sama dengan nol maka nilai ROA sebesar 2181,435

2.Nilai CR sebesar -3,151 Dengan koefisien negatif yang artinya setiap CR menurun satu satuan maka ROA akan mengalami penurunan sebesar 3,151 satuan.

Dan dari signifikansi untuk perusahaan kosmetik sebesar $=0,072$ yang berarti > signifikansi $=0,05$ ini berarti secara parsial antara variabel independent dan variabel dependent tidak mempunyai pengaruh. Dan ini berarti Ho diterima.

Analisa R square/R Determinan pada Current Rasio terhadap ROA

Tabel 2

Model Summary CR terhadap ROA

\begin{tabular}{|c|c|c|c|c|}
\hline Model & $\mathrm{R}$ & $\begin{array}{c}\mathrm{R} \\
\text { Square }\end{array}$ & $\begin{array}{c}\text { Adjusted R } \\
\text { Square } \\
\end{array}$ & $\begin{array}{c}\text { Std. Error of the } \\
\text { Estimate }\end{array}$ \\
\hline 1 & $.366^{\mathrm{a}}$ & .134 & .096 & 1773.978 \\
\hline
\end{tabular}

Sumber : Hasil Olahan SPSS 20

Dari tabel diatas $\mathrm{R}^{2} \quad / \mathrm{R}$ Determinasi $=0,134$ akan diubah menjadi prosentase yaitu $13,4 \%$ yang artinya Current rasio memberikan pengaruh terhadap Return On assets sedangkan sisanya dipengaruhi variabel lain yang tidak diteliti.

Analisis Regresi

Pada Debt to Equity rasio Terhadap Return on Assets:

Tabel 3

\section{Coefficients DER terhadap ROA}

\begin{tabular}{lrrrrrr}
\hline \multirow{2}{*}{ Model } & \multicolumn{2}{c}{$\begin{array}{c}\text { Unstandardized } \\
\text { Coefficients }\end{array}$} & \multicolumn{2}{c}{$\begin{array}{c}\text { Standardized } \\
\text { Coefficients }\end{array}$} & t & Sig. \\
\cline { 2 - 5 } & \multicolumn{1}{c}{ B } & Std. Error & Beta & & \\
\hline \multirow{2}{*}{1 (Constant) } & 1643.966 & 684.273 & & 2.402 & .025 \\
\cline { 2 - 6 } & DER & -11.742 & 18.763 & -.129 & -.626 & .538 \\
\hline
\end{tabular}

Sumber : Hasil Olahan SPSS 20

Dari tabel diatas didapat persamaan regresi linier sederhana sebagai berikut:

$\mathrm{ROA}=1643,966-11,742 \mathrm{X} 1$

Interprestasi yang di dapat dinyatakan dari persamaan diatas sebagai berikut: 
1. Nilai kontantan sebesar 1643,966 yang artinya jika nilai DER ( Debt To Equity Rasio) memiliki nilai sama dengan nol maka nilai ROA sebesar 1643,966

2. Nilai DER sebesar -11,742 Dengan koefisien negatif yang artinya setiap DER menurun satu satuan maka ROA akan mengalami penurunan sebesar 11,742 satuan.

Dari signifikansi untuk perusahaan kosmetik sebesar $=0,538$ yang berarti > signifikansi $=0,05$ ini berarti secara parsial antara variabel independent dan variabel dependent tidak mempunyai pengaruh. Dan ini berarti Ho diterima.

Analisa $R$ square/R Determinan pada Debt to Equity Rasio terhadap ROA

\section{Tabel 4}

Model Summary DER terhadap ROA

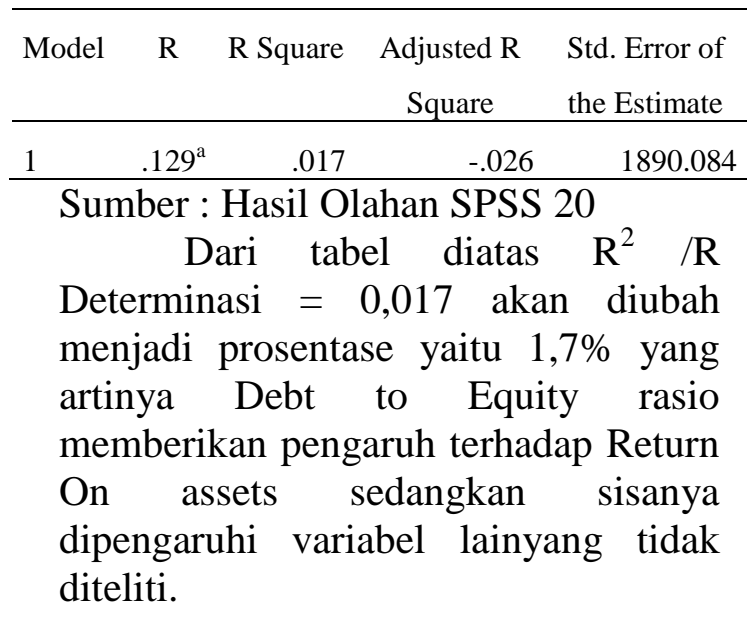

\section{PENUTUP}

\section{Kesimpulan}

Berdasarkan dari hasil
penelitian diperoleh kesimpulan sebagai berikut: (1)Berdasarkan hasil Uji regresi secara parsial pada Current rasio terhadap ROA didapat nilai signifikansi probabilitasnya sebesar 0,072 yang berarti > signifikansi $=0,05$ ini berarti secara parsial antara variabel independent dan variabel dependent tidak mempunyai pengaruh. (2) Berdasarkan hasil Uji regresi secara parsial pada Debt to Equity rasio terhadap ROA didapat nilai signifikansi probabilitasnya sebesar 0,538 yang berarti $>$ signifikansi $=0,05$ ini berarti secara parsial antara variabel independent dan variabel dependent tidak mempunyai pengaruh. (3) Berdasarkan Uji R Determinasi pada Current rasio terhadap ROA mempunyai pengaruh sebesar $13,4 \%$. (4) Berdasarkan Uji R Determinasi pada Debt to Equity rasio terhadap ROA mempunyai pengaruh sebesar 1,7\%.(5) Uji dominan lebih besar terdapat pada Current rasio terhadap ROA $13,4 \%$ dibandingkan dengan hasil uji dominan Debt to Equity rasio terhadap ROA yang hanya sebesar $1,7 \%$.

Saran

Berdasarkan kesimpulan diatas maka saran yang dapat diberikan sebagai berikut:(1) Pada hasil uji $\mathrm{R}$ Determinansi hanya sebesar 13,4\% terhadap ROA sehingga pengaruh sisanya sebesar $86,6 \%$ di pengaruhi faktor lain,hal ini diharapkan perusahaan lebih meningkatkan kemampuan membayar kewajiban jangka pendeknya dengan tepat waktu.(2). Pengaruh sebesar 1,7\% pada DER terhadap ROA, diharapkan perusahaan lebih mengetahui jumlah dana yang disediakan pinjaman dengan pemilikan perusahaan. (3) peneliti selanjutnya diharapkan perlu memperbanyak sampel dan variabel bebas .

\section{DAFTAR PUSTAKA}

Fahmi, Irham. (2015). Analisis Laporan Keuangan, Edisi Pertama. Alfabeta,Bandung.

Ghozali,Imam. (2005). Aplikasi Analisis Multivariate dengan Program SPSS edisi 
Keempat.Penerbit Universitas Diponegoro

Ghozali,Imam. (2016). .Aplikasi Analysis Multivariate dengan Program SPSS, Semarang: Badan Penerbit Universitas Diponegoro

Hasanuh, Nanu. (2011). Akuntansi Dasar : Teori dan Praktik, Edisi Pertama. Mitra Wacana Media. Jakarta.

Hery. (2015). Analisis Laporan Keuangan, PT Buku Seru. Cet 1. Yogyakarta.

Kasmir. (2011). Analisis Laporan Keuangan, Edisi Pertama (Revisi). PT RajaGrafindo Persada. Jakarta.

Kuncoro, Mudrajad. (2011). Metode Kuantitatif, Edisi Empat. Unit Penerbit dan Percetakan Sekolah Tinggi Ilmu Manajemen. Yogyakarta

Milyati, Rina. (2017).Uji parsial current rasio,debt to equity rasio dan inventory turnover terhadap return on assets pada perusahaan makanan dan minuman yang terdaftar di bursa efek indonesia, Jurnal ilmiah gema ekonomi:7(1) Februari,STIE Prasetiya Mandiri Lampung.

Milyati, Rina. (2017). Pengaruh Dominan current ratio,debt to assets ratio,total assets turnover terhadap return on equity pada perusahaan makanan dan minuman di bursa efek Indonesia,Optimum: Jurnal ekonomi dan pembangunan: 7(1) Maret,Universitas Ahmad Dahlan Yogyakarta.

Milyati, Rina. (2016). Pengaruh Dominan cash ratio dan debt to assets rastio terhadap Return on Equity dan return on assets pada perusahaan transportasi di bursa efek Indonesia, Jurnal Manajemen Magister Darmajaya:2(1) Januari,IIB Darmajaya Lampung.

Munawir. (2010). Analisa Laporan Keuangan, Edisi Keempat. Liberty.Yogyakarta.

Sartono, A. (2001). Manajemen keuangan: Teori dan Aplikasi. Edisi Keempat. Cetakan Pertama.Yogyakarta:BPFE 
2018. Journal of Economic, Business and Accounting (COSTING) 1(2):316-325 